\title{
Figure S3
}

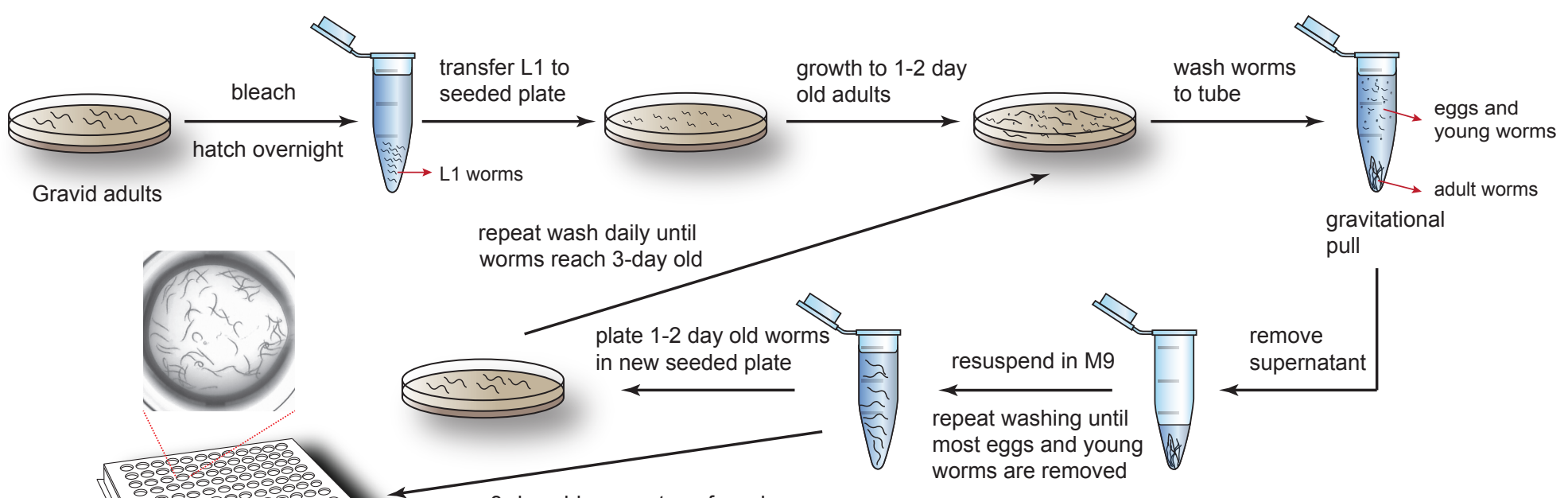

3-day old worms transferred

to 96-well plate for WMicrotracker 